Check for updates

Cite this: RSC Adv., 2017, 7, 36612

Received 18th June 2017

Accepted 15th July 2017

DOI: $10.1039 / \mathrm{c} 7 \mathrm{ra06778j}$

rsc.li/rsc-advances

\section{Multifunctional organic dyes: anion-sensing and light-harvesting properties of curcumin boron complexes $\dagger$}

\author{
Masahiro Tsuchikawa, ${ }^{a}$ Aya Takao, ${ }^{a}$ Takashi Funaki, ${ }^{\mathrm{b}}$ Hideki Sugihara ${ }^{\mathrm{b}}$ \\ and Katsuhiko Ono (D) *a
}

Organoboron compounds containing curcumin (i.e. natural phenols) were synthesised as a new type of multifunctional organic dye. These compounds behaved as sensing indicators for $\mathrm{pH}$ and anions in mineral waters while exhibiting sensitiser ability in dye-sensitised solar cells.

\section{Introduction}

The fabrication of high-performance, low-cost dye-sensitised solar cells (DSCs) has attracted considerable attention in the past decade. ${ }^{1-3}$ DSCs have been recently proposed as highly attractive subjects for the research and development of wearable technologies owing to their flexibility and simple fabrication process. ${ }^{4}$ For example, DSCs have been studied for textileformed devices. ${ }^{5}$ Their utilisation in wearable devices have posed new requirements on DSCs. Thus, wearable devices require components having human and environmental safety and sustainability characteristics that can be met by using natural materials. However, natural dyes satisfying such demands have not been found yet in this field. ${ }^{6,7}$

Organoboron compounds are of interest as sensing ${ }^{8}$ and light-harvesting ${ }^{9,10}$ materials, and these properties can be useful for the development of wearable technologies. Curcumin, a yellow dye found in turmeric and curry powders, ${ }^{6 b}$ is one of the natural phenols containing a 1,3-diketone skeleton that chelates boron reagents to afford red dyes. Rosocyanin is a wellknown curcumin boron complex exhibiting chromism characteristics depending on the $\mathrm{pH}$ conditions. ${ }^{11}$ Curcumin difluoroboron complexes have been reported to show colour change to aqueous cyanine solution and serve as its indicator. ${ }^{12} \mathbf{C B}$ is also of interest because it has a polar structure similar to those of rosocyanin and the related compounds (Scheme 1) ${ }^{13}$ In resonance hybrids, a positive charge is delocalised on the $\beta$-diketonate moiety, while a negative charge is localised on the boron atom. Thus, we synthesised compounds 1-4 as a new type of

${ }^{a}$ Graduate School of Engineering, Nagoya Institute of Technology, Gokiso, Showa-ku, Nagoya 466-8555, Japan. E-mail: ono.katsuhiko@nitech.ac.jp

${ }^{b}$ National Institute of Advanced Industrial Science and Technology, Higashi, Tsukuba 305-8565, Japan

$\dagger$ Electronic supplementary information (ESI) available: Synthesis and characterisation of dyes, analytical studies, theoretical calculations, photovoltaic fabrication, spectra and movies. See DOI: 10.1039/c7ra06778j multifunctional organic dye for sensing device and DSC applications. Some of these compounds showed chromism depending upon solvents, $\mathrm{pH}$ conditions and adding mineral waters, and they exhibited higher sensitiser performances in DSCs than in simple natural dyes. We report herein the sensing and light-harvesting properties of $\mathbf{1 - 4}$ and $\mathbf{C B}$.

\section{Results and discussion}

Compounds 1-4 and CB were synthesised in $60-88 \%$ yields by boron-chelation of curcumin, catechol derivatives and tributyl borate under refluxing toluene conditions (ESI $\dagger$ ). These compounds were obtained as deep red crystals which were stable in air in their solid state. Their structures were determined by spectral data and elemental analyses (ESI $\dagger$ ). The ${ }^{11} \mathrm{~B}$ NMR spectra revealed that the electronic properties at the boron-chelating moieties were almost similar to each other, with minor down- and up-field shifts produced by the carboxyl and octyl groups being observed, respectively $(\delta / \mathrm{ppm}=9.27(\mathbf{1})$, $9.00(2), 9.13$ (3), 9.11 (4) and 9.08 (CB) as a standard of

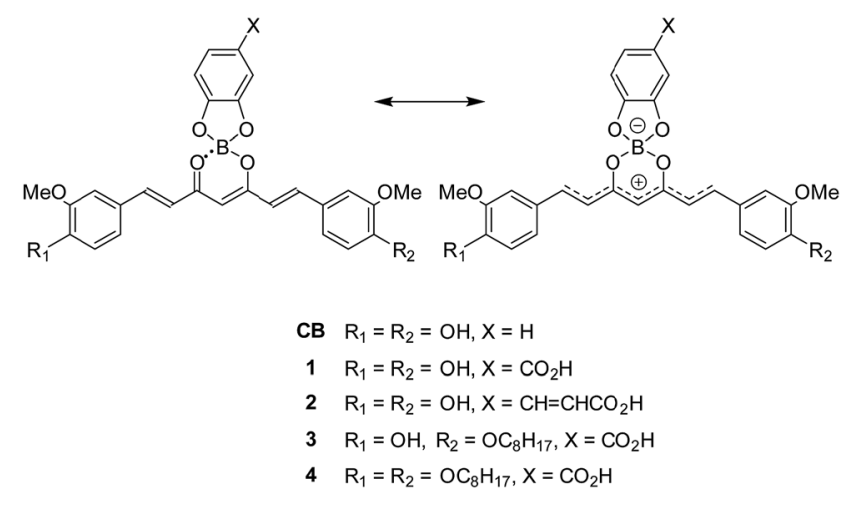

Scheme 1 Structure of curcumin boron complexes with resonance hybrids, in which a positive charge is delocalised on the $\beta$-diketonate moieties and a negative charge is localised on the boron atoms. 
$\left.\mathrm{BF}_{3} \cdot \mathrm{OEt}_{2}\right)$. The compounds were stable in aprotic solvents for periods ranging from a week to over a month (Fig. S1 and S2, ESI $\dagger$ ). However, they underwent hydrolysis within a few days in ethanol and methanol yielding the corresponding curcumin derivatives.

The UV-Vis absorption maxima of 1-4 and $\mathbf{C B}$ in acetonitrile were observed in the wavelength region of $503-514 \mathrm{~nm}$ $\left(\varepsilon>70000 \mathrm{M}^{-1} \mathrm{~cm}^{-1}\right.$ ) (Table 1$)$. Thus, boron-chelating curcumin possessed a good visible light-harvesting ability. 1-3 and CB displayed solvatochromism in various solvents (Fig. S3, ESI $\dagger$ ), and the absorption spectra of $\mathbf{1}$ are shown in Fig. 1a. This phenomenon was attributed to the deprotonation of the phenol groups because 4 did not show solvatochromism. When dissolved in DMF, 1 showed new absorption bands having maxima at 704, 645 and $597 \mathrm{~nm}$ apart from the absorption band at $546 \mathrm{~nm}$ (Table 1). When dissolved in DMSO, new absorption bands were also observed for $\mathbf{1}$. The intensity of these absorption bands increased while decreasing the solution concentration (Fig. S5, ESI $\dagger$ ). The long-wavelength absorption bands rapidly disappeared upon ultrasonication, and the colour shifted from blue to red (Fig. S6a and b and Movie S1, ESI $\dagger$ ). Since chromism was not observed in a buffer solution at $\mathrm{pH}=10$ (Fig. S6c, ESI $\dagger$ ), this phenomenon was attributed to a decrease in the $\mathrm{pH}$ values of the solvents upon ultrasonication in air.

With the aim to promote deprotonation of the phenol groups, triethylamine (TEA) was added to the solution of $\mathbf{1}$ in acetonitrile (Fig. 1b). Upon increasing TEA concentration, the intensity of the absorption band at $c a .510 \mathrm{~nm}$ decreased and new absorption bands appeared in the wavelength region of $537-750 \mathrm{~nm}$. The spectral change revealed an isosbestic point at $537 \mathrm{~nm}$, thereby suggesting that the new absorption bands were produced upon generation of a phenoxide monoanion on the curcumin skeleton. The ${ }^{1} \mathrm{H}$ NMR spectra of $\mathbf{C B}$ were determined while increasing the concentration of TEA (Fig. 2). All the peaks assigned to the $\pi$-conjugated system upfield shifted. ${ }^{13}$ In particular, large shifts were observed at the positions of $\mathrm{H} 1, \mathrm{H} 2$, $\mathrm{H} 3$ and $\mathrm{H} 4$, thereby indicating that the $\pi$-conjugated system had a significant contribution in the resonance of the hybrids (Scheme 1). The TEA-induced chromism was also found in a titanium oxide $\left(\mathrm{TiO}_{2}\right)$ film, as shown in Fig. S8 (ESI $\dagger$ ). The original colour was immediately recovered upon evaporation of TEA, whereas coating the TEA-treated dye substrate with manicure allowed to maintain the colour (Fig. S9, ESI $\dagger$ ). Fig. 1c shows the absorption spectra of $\mathbf{1}$ under several $\mathrm{pH}$ conditions in DMSO containing 10 vol\% of water. Neutral species of 1 was

Table 1 UV-Vis absorption maxima of $1-4$ and $\mathrm{CB}$ in MeCN and $\mathrm{DMF}^{a}$

\begin{tabular}{lll}
\hline Dye & $\lambda_{\max }(\mathrm{nm})(\varepsilon)^{b}$ in MeCN & $\lambda_{\max }(\mathrm{nm})$ in DMF \\
\hline $\mathbf{1}$ & $509(78900)$ & $704,645,597,546$ \\
$\mathbf{2}$ & $508(73500)$ & $704,645,598,546$ \\
$\mathbf{3}$ & $512(81700)$ & $704,644,597,543$ \\
$\mathbf{4}$ & $514(74700)$ & 523 \\
CB & $503(79400)$ & $702,645,599,535$ \\
${ }^{a}$ Conc. $1.0 \times 10^{-5} \mathrm{M} .^{b} \mathrm{M}^{-1} \mathrm{~cm}^{-1}$. &
\end{tabular}

(a)

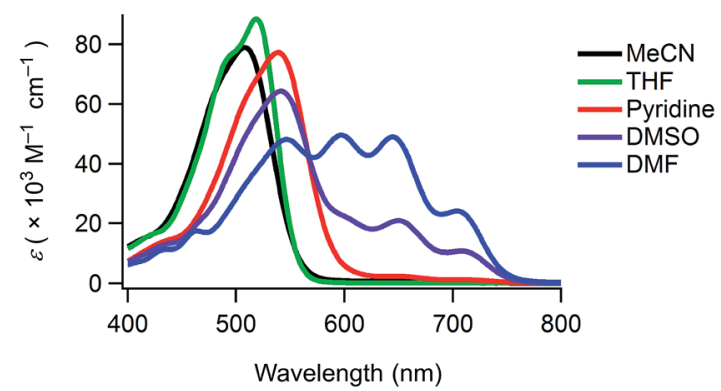

(b)

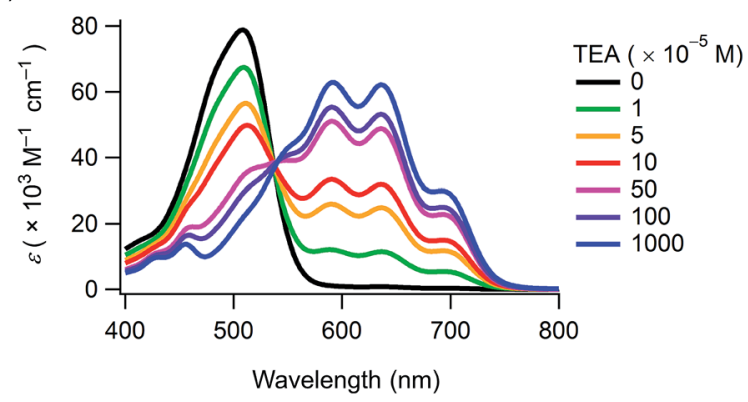

(c)

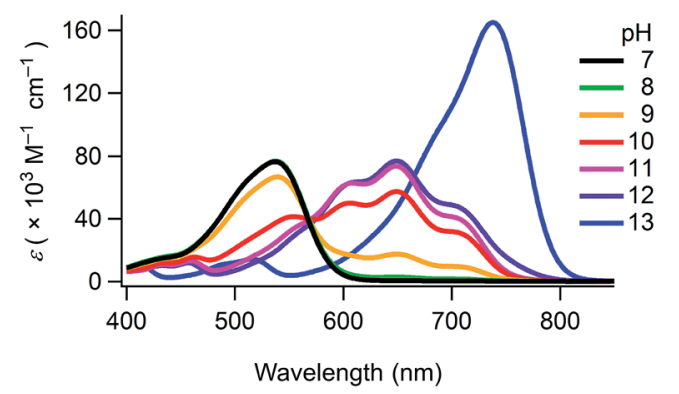

Fig. 1 UV-Vis absorption spectra of 1 (conc. $1.0 \times 10^{-5} \mathrm{M}$ ): (a) in various solvents, (b) in acetonitrile solutions containing TEA (conc. 0 , $1.0 \times 10^{-5}, 5.0 \times 10^{-5}, 1.0 \times 10^{-4}, 5.0 \times 10^{-4}, 1.0 \times 10^{-3}$ and $1.0 \times$ $\left.10^{-2} \mathrm{M}\right)$ and $(\mathrm{c})$ under several $\mathrm{pH}$ conditions $(\mathrm{pH}=7-13)$ in DMSO containing 10 vol\% of water.

found under neutral and acidic solutions at $\mathrm{pH}=7$ or below, and its absorption maximum was observed at $537 \mathrm{~nm}$. The absorption bands of $\mathbf{1}$ and its phenoxide monoanion were both observed at basic $\mathrm{pH}$ values ranging from 8 to 10 . At higher $\mathrm{pH}$ values (i.e. 11 and 12), the spectra of the solutions indicated that 1 mainly existed as a phenoxide monoanion. The spectral change at $\mathrm{pH}=7-11$ revealed an isosbestic point at $568 \mathrm{~nm}$. When dissolved in a strongly basic solution $(\mathrm{pH}=13)$, a new absorption band having a maximum at $738 \mathrm{~nm}$ was observed for 1. Since this new band was not observed for a solution containing 3 (Fig. S10, ESI $\dagger$ ), we inferred that the onset of this new absorption band was produced upon generation of a phenoxide dianion. Addition of acid to the solution of the phenoxide dianion recovered the neutral species of $\mathbf{1}$. In the above conditions, the first acid dissociation constants $\left(\mathrm{p} K_{\mathrm{a} 1}\right)$ were determined to be 9.5, 9.7 and 9.7 for $\mathbf{1}, 3$ and $\mathbf{C B}$, respectively. The second acid dissociation constants $\left(\mathrm{p} K_{\mathrm{a} 2}\right)$ were determined to be 12.5 and 11.5 for 1 and $\mathbf{C B}$, respectively (Fig. S11, ESI $\dagger$ ). The UV-Vis absorption spectra of $\mathbf{C B}$ and its monoanion and dianion 


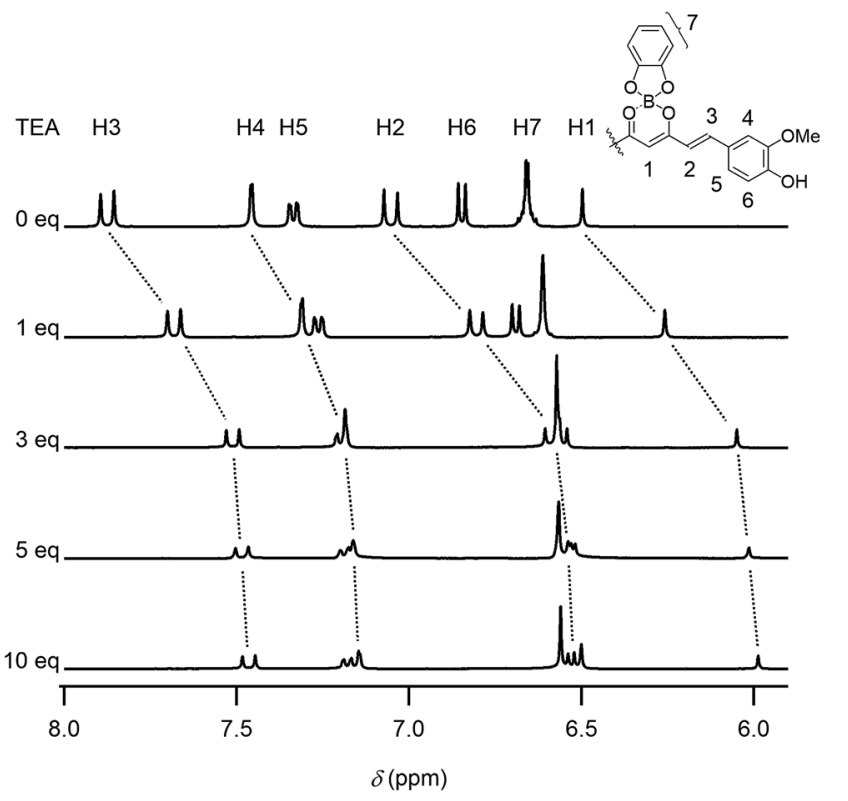

Fig. $2{ }^{1} \mathrm{H}$ NMR spectra of CB $\left(1.7 \times 10^{-2} \mathrm{M}\right)$ in DMSO- $d_{6}$ solutions containing TEA $(0,1,3,5$ and 10 mol equiv.).

species were simulated by using time-dependent density functional theory (TDDFT) calculations at the B3LYP/6-31G(d) level (Fig. S12, ESI $\dagger$ ). The theoretical spectra supported the absorption redshifts in the experimental spectra of the monoanion and dianion species.

The chromism was attributed to the polar structure generated on the curcumin skeleton (Scheme 1). This $\pi$-electron system can be used for detecting ions in water. When water was dropwise added to a dye DMSO solution, the red solution turned blue, as shown in Fig. 3a (see also Movie S2, ESI†). In contrast, this colour change was not observed when pure water was added. The UV-Vis absorption spectra of DMSO solutions of $\mathbf{1}$ containing mineral waters are shown in Fig. $3 \mathrm{~b}$ and S13 (ESI $\dagger$ ). The absorption bands in the wavelength region of 567-780 nm increased with the amount of minerals added. With the aim to determine the ion species causing chromism, the ion selectivity of $\mathbf{C B}$ was investigated (Table S1 and S2, ESI $\dagger$ ). These studies revealed that cationic species did not generate chromism. Indeed, anions such as $\mathrm{OH}^{-}, \mathrm{PO}_{4}{ }^{3-}, \mathrm{CO}_{3}{ }^{2-}, \mathrm{HPO}_{4}{ }^{2-}, \mathrm{HCO}_{3}{ }^{-}$, $\mathrm{CH}_{3} \mathrm{CO}_{2}{ }^{-}, \mathrm{F}^{-}$and $\mathrm{SO}_{4}{ }^{2-}$ were responsible for this phenomenon. On the other hand, no colour change was observed when very weak bases such as $\mathrm{BF}_{4}^{-}, \mathrm{NO}_{3}{ }^{-}, \mathrm{ClO}_{4}{ }^{-}$and $\mathrm{Cl}^{-}$were used, thereby suggesting a basicity boundary between active and inactive anions at $c a . \mathrm{p} K_{\mathrm{b}}=12$ in water. According to the Job's plots for $\mathbf{C B}$ and sodium salts, a $\mathbf{C B}$ to $\mathrm{Na}_{2} \mathrm{CO}_{3}$ molar ratio of $2: 1$ was observed (Fig. 3c). Thus, both $\mathrm{CO}_{3}{ }^{2-}$ and $\mathrm{HCO}_{3}{ }^{-}$ species were able to deprotonate the phenol groups of the curcumin moiety to generate the monoanion of $\mathbf{C B}$. On the other hand, a molar ratio of $1: 1$ was measured when $\mathrm{NaOH}$ and $\mathrm{Na}_{2} \mathrm{SO}_{4}$ were used. In $\mathrm{Na}_{2} \mathrm{SO}_{4}$ solution, $\mathrm{SO}_{4}{ }^{2-}$ (and not $\mathrm{HSO}_{4}{ }^{-}$) was the active species to $\mathrm{CB}$. Furthermore, when using $\mathrm{Na}_{3} \mathrm{PO}_{4}$, a CB to $\mathrm{Na}_{3} \mathrm{PO}_{4}$ molar ratio of $2: 1$ (instead of $3: 1$ ) was observed, thereby indicating that both $\mathrm{PO}_{4}{ }^{3-}$ and $\mathrm{HPO}_{4}{ }^{2-}$ (a)

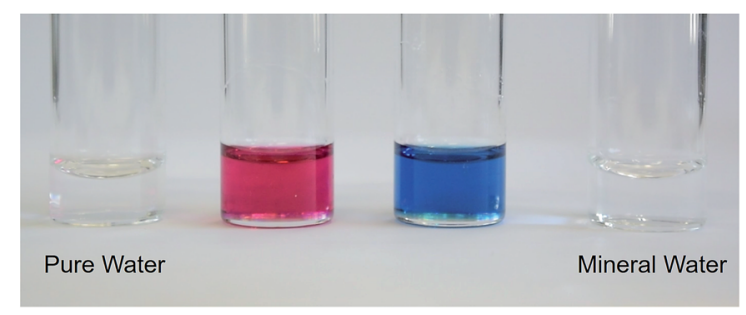

(b)

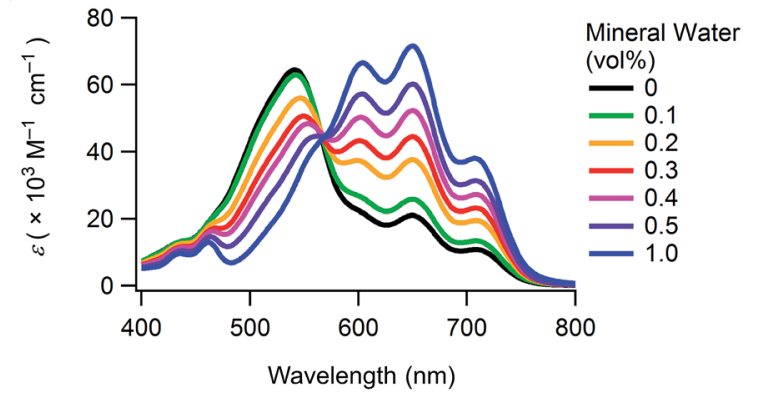

(c)

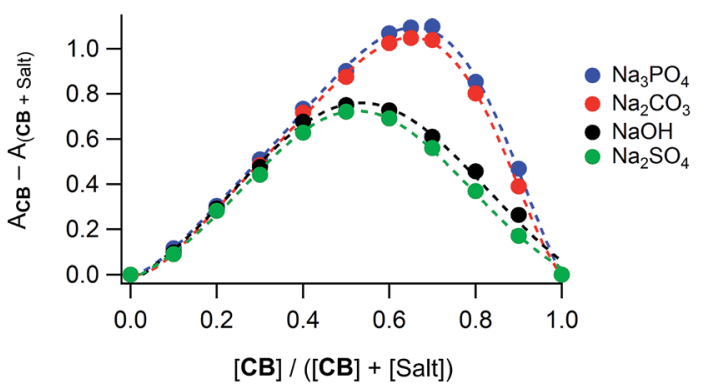

Fig. 3 Anion-sensing properties: (a) chromism of 1 (conc. $5.0 \times$ $10^{-5} \mathrm{M}$ in DMSO) upon addition of mineral water (see also Movie S2, ESI $\dagger$ ), (b) UV-Vis absorption spectra of 1 (conc. $1.0 \times 10^{-5} \mathrm{M}$ ) in DMSO solutions containing several amounts of mineral water (hardness $40 \mathrm{mg} \mathrm{L}^{-1}, \mathrm{pH}=6.8$ ) and (c) Job's plots for CB (conc. $3.0 \times 10^{-5} \mathrm{M}$ ) and sodium salts in DMSO containing 10 vol\% of water (monitored at $648 \mathrm{~nm}$ ), indicating $\mathrm{CB}$ to sodium salts molar ratios of $1: 1(\mathrm{NaOH}$ and $\left.\mathrm{Na}_{2} \mathrm{SO}_{4}\right)$ and $2: 1\left(\mathrm{Na}_{2} \mathrm{CO}_{3}\right.$ and $\left.\mathrm{Na}_{3} \mathrm{PO}_{4}\right)$.

species were active (and $\mathrm{H}_{2} \mathrm{PO}_{4}^{-}$was inactive) for generating chromism. Thus, these dyes were useful indicators for sensing anions in mineral waters.

With the aim to investigate the light-harvesting properties of the curcumin boron complexes, dyes 1-4 were used in DSCs (ESI†). Fig. 4a shows the current density-voltage characteristics of the DSCs containing dyes 1-4 (denoted as DSCs 1-4). The short-circuit photocurrent density $\left(U_{\text {sc }}\right)$, open-circuit photovoltage $\left(V_{\mathrm{oc}}\right)$, fill factor $(\mathrm{FF})$ and solar-to-electric power conversion efficiency (PCE) of these DSCs are listed in Table 2. The PCEs varied with $J_{\mathrm{sc}}$, and DSCs 2 and $\mathbf{3}$ showed higher PCEs as compared to DSCs employing curcumin $(0.36 \%)^{6 b}$ or other natural dyes $(<2 \%)^{6 a}$ with the exception of chlorophyll ${ }^{7 a}$ and a few more. ${ }^{7 b}$ These PCEs were also much higher than that of a similar boron complex $(0.34 \%) .{ }^{14}$ DSC 2 showed higher PCEs as compared to DSC $\mathbf{1}$ as a result of dye modification by substitution of 3,4-dihydroxybenzoic acid with caffeic acid. However, the $J_{\mathrm{sc}}$ of DSC 2 gradually decreased with time. The 
(a)

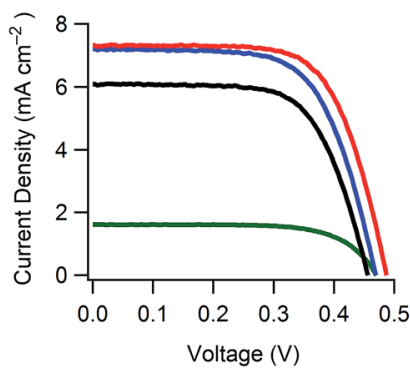

(b)

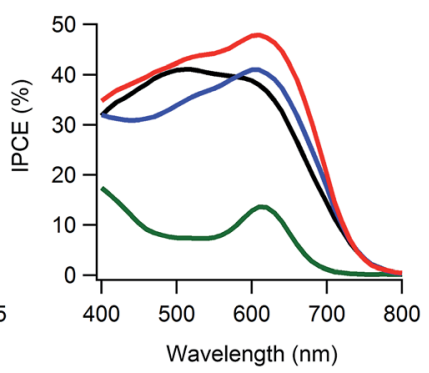

Fig. 4 Photovoltaic performance for DSCs 1-4: (a) current densityvoltage characteristics and (b) IPCE spectra; black line: DSC 1, blue line: DSC 2, red line: DSC 3 and green line: DSC 4.

Table 2 Photovoltaic performance of DSCs $1-4^{a}$

\begin{tabular}{lllll}
\hline DSC & $J_{\text {sc }}\left(\mathrm{mA} \mathrm{cm}^{-2}\right)$ & $V_{\text {oc }}(\mathrm{V})$ & FF & PCE $(\%)$ \\
\hline $\mathbf{1}$ & 6.1 & 0.46 & 0.66 & 1.8 \\
2 & 7.2 & 0.47 & 0.65 & 2.2 \\
3 & 7.3 & 0.49 & 0.67 & 2.4 \\
$\mathbf{4}$ & 1.6 & 0.47 & 0.69 & 0.5
\end{tabular}

a DSC conditions: irradiation of $100 \mathrm{~mW} \mathrm{~cm}^{-2}$ (AM 1.5 solar light); photoelectrode: $\mathrm{TiO}_{2}$ films $\left(17 \mu \mathrm{m}\right.$ thickness and $0.25 \mathrm{~cm}^{2}$ area) coated with dye acetonic solutions $(0.2 \mathrm{mM})$; electrolyte: $0.60 \mathrm{M} \mathrm{1,2-}$ dimethyl-3-propylimidazolium iodide (DMPII), $0.05 \mathrm{M} \mathrm{I}_{2}$ and $0.10 \mathrm{M}$ LiI in acetonitrile.

highest PCE was obtained for DSC 3 containing a monoalkylated curcumin dye. Furthermore, DSC 4 (containing a dialkylated curcumin dye) did not achieve effective photoelectric conversion. The incident photo-to-current conversion efficiency (IPCE) spectra are shown in Fig. 4b. DSCs 1, 2 and 3 showed maximum efficiencies of 41,41 and $48 \%$, respectively. These values were relatively low against their light-harvesting abilities. The electrochemical characteristics of these dyes are shown in Fig. S14 (ESI $\dagger$ ). The dyes showed reduction waves at $-0.6 \mathrm{~V}$ versus the normal hydrogen electrode (NHE) potential. These reduction potentials were close to $-0.5 \mathrm{~V}$ of the $\mathrm{TiO}_{2}$ photoanode, suggesting that a driving force for effective electroninjection was insufficient in the DSC performance. ${ }^{15}$ Therefore, the PCEs would be improved by optimization of LUMO energies.

We investigated the effect of adding TEA, trihexylamine (THA) or 4-tert-butylpyridine (TBP) to the electrolyte solutions of DSCs 1-3. DSCs 1-3 containing 0.01 M of TEA exhibited PCEs of 1.8, 2.2 and $2.4 \%$, respectively. These values were similar to those in Table 2 despite the TEA concentration $(0.01 \mathrm{M})$ was enough to deprotonate the phenol groups (Fig. S8, ESI†). This fact suggested that phenoxide monoanions were generated in DSCs 1-3 even without TEA. DSCs 1-3 containing $0.01 \mathrm{M}$ of THA showed PCEs of 2.0, 2.2 and 2.4\%, respectively. The PCE of DSC 1 slightly increased upon addition of THA, thereby suggesting a charge recombination inhibition effect on the $\mathrm{TiO}_{2}$ photoanode. Furthermore, DSCs 1-3 containing $0.01 \mathrm{M}$ of TBP exhibited PCEs of 1.5, 1.7 and 2.4\%, respectively. The PCEs of
DSCs 1 and 2 decreased upon addition of TBP, thereby indicating that the interaction of TBP with the $\mathrm{TiO}_{2}$ photoanodes weakened the electron-injection from the excited dyes to the $\mathrm{TiO}_{2}$ photoanodes. ${ }^{16}$ The three additives had no influence on the PCEs of DSC 3.

\section{Conclusions}

We synthesised curcumin boron complexes possessing sensing and light-harvesting abilities. The solutions of these compounds exhibited chromism depending on the solvent, ultrasonication and $\mathrm{pH}$ conditions. Addition of amines or mineral waters were also effective in generating chromism because the curcumin moiety having two phenol groups was highly polarised via boron chelation. We investigated the structural changes among neutral, phenoxide monoanion and dianion species by UV-Vis absorption and ${ }^{1} \mathrm{H}$ NMR spectral analyses. The first and second acid dissociation constants in DMSO containing 10 vol\% of water were measured to be $c a \cdot \mathrm{p} K_{\mathrm{a} 1}$ $=9.5$ and $\mathrm{p} K_{\mathrm{a} 2}=12$, respectively. These dyes exhibited chromism via deprotonation with anions having $\mathrm{p} K_{\mathrm{b}}$ values in water below ca. 12. This anion recognition ability is useful for the analysis of mineral waters. When loaded on $\mathrm{TiO}_{2}$ substrates, these dyes also demonstrated chromism depending on the environment. Furthermore, they showed light-harvesting abilities in the visible wavelength region. DSCs containing these organoboron compounds exhibited PCEs of $1.8-2.4 \%$, and a PCE of $2.2 \%$ was achieved by a DSC containing a boron complex of curcumin and caffeic acid. These PCEs were higher than those obtained with simple natural dyes. Modification of curcuminoids via boron chelation is useful for the research and development of new types of DSCs to be employed in the wearable technology field.

\section{Acknowledgements}

This work was supported by the Asahi Glass Foundation, Takahashi Industrial and Economic Research Foundation and JSPS KAKENHI Grant Number JP15K05422. Theoretical calculations were performed using Research Center for Computational Science, Okazaki, Japan.

\section{Notes and references}

1 B. O'Regan and M. Grätzel, Nature, 1991, 353, 737.

2 (a) S. Mathew, A. Yella, P. Gao, R. Humphry-Baker, B. F. E. Curchod, N. Ashari-Astani, I. Tavernelli, U. Rothlisberger, M. K. Nazeeruddin and M. Grätzel, Nat. Chem., 2014, 6, 242; (b) K. Kakiage, Y. Aoyama, T. Yano, T. Otsuka, T. Kyomen, M. Unno and M. Hanaya, Chem. Commun., 2014, 50, 6379; (c) Z. Yao, M. Zhang, H. Wu, L. Yang, R. Li and P. Wang, J. Am. Chem. Soc., 2015, 137, 3799.

3 M. Graetzel, R. A. J. Janssen, D. B. Mitzi and E. H. Sargent, Nature, 2012, 488, 304.

4 A. Hagfeldt, G. Boschloo, L. Sun, L. Kloo and H. Pettersson, Chem. Rev., 2010, 110, 6595. 
5 (a) S. Pan, Z. Yang, P. Chen, J. Deng, H. Li and H. Peng, Angew. Chem., Int. Ed., 2014, 53, 6110; (b) M. J. Yun, S. I. Cha, S. H. Seo, H. S. Kim and D. Y. Lee, Sci. Rep., 2015, 5, 11022; (c) W. Weng, P. Chen, S. He, X. Sun and H. Peng, Angew. Chem., Int. Ed., 2016, 55, 6140.

6 (a) M. R. Narayan, Renewable Sustainable Energy Rev., 2012, 16, 208; (b) S. A. M. Al-Bat'hi, I. Alaei and I. Sopyan, Int. J. Renew. Energy Res., 2013, 3, 138.

7 (a) X.-F. Wang, Y. Koyama, O. Kitao, Y. Wada, S. Sasaki, H. Tamiaki and H. Zhou, Biosens. Bioelectron., 2010, 25, 1970; (b) W. Maiaugree, S. Lowpa, M. Towannang, P. Rutphonsan, A. Tangtrakarn, S. Pimanpang, P. Maiaugree, N. Ratchapolthavisin, W. Sang-aroon, W. Jarernboon and V. Amornkitbamrung, Sci. Rep., 2015, 5, 15230.

8 (a) J. Hu, Z. He, Z. Wang, X. Li, J. You and G. Gao, Tetrahedron Lett., 2013, 54, 4167; (b) K. Tanaka and Y. Chujo, NPG Asia Mater., 2015, 7, e223.

9 (a) Y.-D. Lin, B.-Y. Ke, Y. J. Chang, P.-T. Chou, K.-L. Liau, C.-Y. Liu and T. J. Chow, J. Mater. Chem. A, 2015, 3, 16831; (b) Y. Kubo, D. Eguchi, A. Matsumoto, R. Nishiyabu, H. Yakushiji, K. Shigaki and M. Kaneko, J. Mater. Chem. A, 2014, 2, 5204; (c) S. B. Mane, J.-Y. Hu, Y.-C. Chang, L. Luo, E. W.-G. Diau and C.-H. Hung, Chem. Commun., 2013, 49, 6882; (d) M. Mao, X.-L. Zhang, X.-Q. Fang, G.-H. Wu, Y. Ding, X.-L. Liu, S.-Y. Dai and Q.-H. Song, Org. Electron., 2014, 15, 2079; (e) J. A. Mikroyannidis, M. S. Roy and G. D. Sharma, J. Power Sources, 2010, 195, 5391; (f) M. Mao,
X.-L. Zhang, X.-Q. Fang, G.-H. Wu, S.-Y. Dai, Q.-H. Song and X.-X. Zhang, J. Power Sources, 2014, 268, 965; $(g)$ Y. Mizuno, Y. Yisilamu, T. Yamaguchi, M. Tomura, T. Funaki, H. Sugihara and K. Ono, Chem.-Eur. J., 2014, 20, 13286.

10 (a) K. Cnops, B. P. Rand, D. Cheyns, B. Verreet, M. A. Empl and P. Heremans, Nat. Commun., 2014, 5, 3406; (b) S. P. Singh, C. H. P. Kumar, G. D. Sharma, J. A. Mikroyannidis, M. Singh and R. Kurchania, J. Polym. Sci., Part B: Polym. Phys., 2012, 50, 1612; (c) T. Bura, N. Leclerc, S. Fall, P. Lévêque, T. Heiser, P. Retailleau, S. Rihn, A. Mirloup and R. Ziessel, J. Am. Chem. Soc., 2012, 134, 17404.

11 G. S. Spicer and J. D. H. Strickland, J. Chem. Soc., 1952, 4644. 12 (a) A. Chaicham, S. Kulchat, G. Tumcharern, T. Tuntulani and B. Tomapatanaget, Tetrahedron, 2010, 66, 6217; (b) D. R. Sherin, S. G. Thomas and K. N. Rajasekharan, Heterocycl. Commun., 2015, 21, 381.

13 A. T. Balaban, C. Párkányi, I. Ghiviriga, J.-J. Aaron, Z. Zajíčková and O. R. Martínez, ARKIVOC, 2008, 1.

14 T. Ganesh, J. H. Kim, S. J. Yoon, B.-H. Kil, N. N. Maldar, J. W. Han and S.-H. Han, Mater. Chem. Phys., 2010, 123, 62. 15 K. Hara, T. Sato, R. Katoh, A. Furube, Y. Ohga, A. Shinpo, S. Suga, K. Sayama, H. Sugihara and H. Arakawa, J. Phys. Chem. B, 2003, 107, 597.

16 K. Hara, Y. Dan-oh, C. Kasada, Y. Ohga, A. Shinpo, S. Suga, K. Sayama and H. Arakawa, Langmuir, 2004, 20, 4205. 